\title{
INDONESIA'S REGIONAL ANTI-CORRUPTION COURTS: SHOULD THEY BE ABOLISHED?
}

\author{
Simon Butt ${ }^{1}$
}

\begin{abstract}
Indonesia's regional anti-corruption courts have been criticised in recent times for perceived impropriety and for acquitting defendants. Senior jurists and politicians have called for these courts to be abolished or recentralised. This article suggests that neither abolition nor recentralisation is prudent and that these criticisms might not be supported by available case statistics. In any event, this article argues, acquittal rates are very poor indicators of judicial performance. Indeed, acquittals might be legally correct, or even necessary, in some cases. More resources should be allocated to these courts, and to the Corruption Eradication Commission so that it can investigate and prosecute more cases in Indonesia's regions.
\end{abstract}

Keywords: corruption, courts, governance, law.

\section{Introduction}

In December 2010, Indonesia's Supreme Court opened the country's first regional anti-corruption (Tipikor or Tindak Pidana Korupsi) courts in Bandung, Surabaya and Semarang to operate alongside the national anti-corruption court, established in Jakarta in 2004. By October 2011, 33 regional anti-corruption courts had been established - one in the district court of each provincial capital. These courts are responsible for adjudicating all corruption and moneylaundering cases that occur in their respective provinces. Previously, a small number of cases involving corruption allegedly occurring in the regions had been tried by the Jakarta Tipikor Court, but most of these cases were handled by the relevant general court located in the province, city or county in which the alleged offence was said to have taken place.

The Indonesian media has been damning of the performance of the regional Tipikor courts since their establishment. Drawing largely on studies and statements by Indonesia Corruption Watch (ICW), the Supreme Court and the Judicial Commission, the media have criticised the Tipikor courts on two main grounds. The first is that the Tipikor Courts have acquitted defendants accused of serious corruption crimes. This is said to have reduced the deterrent effect of the 1999 Anti-corruption Law. ${ }^{2}$ The second ground is the perceived low integrity and competence of many of its serving ad hoc judges and those the Supreme Court was considering appointing in late 2012.

\footnotetext{
${ }^{1}$ Associate Professor, Sydney Law School. I would like to thank Fritz Edward Siregar, SJD candidate at University of New South Wales Law School and researcher at the Centre for Asian and Pacific Law of the University of Sydney (CAPLUS), for his excellent research assistance and help in the preparation of this article. Research for this article was funded by an Australian Research Council Grant (No DP1095541).

${ }^{2}$ Law No 31 of 1999 on the Eradication of Corruption, as amended by Law No 20 of 2001.
} 
Pointing to these two grounds, politicians and senior judges have even called for some or all of the regional Tipikor courts to be shut down. Constitutional Court Chief Justice Mahfud, for example, has urged that all regional Tipikor Courts be disbanded because they are creating legal chaos and performing worse than the general courts ${ }^{3}$. Law and Human Rights Minister Amir Syamsuddin proposed that the regional Tipikor courts be abolished and that all corruption cases be heard in Jakarta. This would make monitoring Tipikor court judges easier, help to ensure objectivity and reduce the number of ad hoc judges that the Supreme Court needed to recruit. ${ }^{4}$

In this article, I argue that closing the regional Tipikor courts will not improve the overall handling of corruption cases in Indonesia. Even though the performance of the Tipikor courts has been far from perfect, the two main criticisms of its performance are misguided and unfair. Acquittals rates are a poor measure with which to judge the success of any court, at least absent an accompanying detailed analysis of the decisions of that court. As I will show, there are many reasons why courts do, should and indeed must acquit. Without an accompanying analysis such as this, acquittals are as likely to be a signal that these courts are working properly as they are an indication of decrepitude. And, even if one does accept - and I do not - that acquittals are an acceptable indicator of performance, the acquittal rates of these courts should not be compared with those of the Jakarta anti-corruption court, which, as is widely known, has maintained close to a 100 per cent conviction rate since opening in 2004. A more appropriate comparison is the acquittal rate of the courts from which the Tipikor courts took jurisdiction in the regions - the general courts.

Claims about the integrity and competence of regional Tipikor court judges might be true but they are hardly exclusive to these new courts. Concerns over the professionalism of the entire Indonesian judiciary have been raised for decades $^{5}$. Judicial competence is also a widespread problem ${ }^{6}$, but criticism of the regional Tipikor courts on this ground is, in my view, unfairly premature and ignores significant challenges faced by the Supreme Court to fill these courts with qualified judges.

This article builds on my previous work on corruption in the Indonesian legal system and attempts at its eradication ${ }^{7}$. It is divided into three parts. Part I concerns Indonesia's Tipikor courts, their establishment and jurisdiction. In Part II, I set out oft-made criticisms of the performance of these courts, before arguing that many of the criticisms directed towards regional Tipikor courts are largely misguided and obscure two 'real' problems that could affect the quality of Tipikor court proceedings and decisions: first, the likely configuration of the bench in some regional Tipikor courts, and second, ordinary prosecutors being allowed to prosecute in regional Tipikor courts. I conclude by discussing

\footnotetext{
${ }^{3}$ Tempo (2012d) Pengadilan Tipikor Daerah Diusulkan Dibubarkan. Tempo. 5 November.

${ }^{4}$ Aritonang. (2012).Goverment ConsidersShutting Down CorruptionCourts in Regions. Jakarta Post. 21 August.

${ }^{5}$ Pompe, S. (2005) The Indonesian Supreme Court: A Study of Institutional Collapse. Studies on Southeast Asia. Ithaca, N.Y: Southeast Asia Program, Cornell University.

${ }^{6}$ Butt, Simon \& Lindsey, Tim. (2010).“Judicial Mafia: The Courts and State Illegality in Indonesia”, in G Van Klinken\& Edward Aspinall (eds.) The state and illegality in Indonesia. KITLV Press.

${ }^{7}$ Butt, Simon.(2009b). 'Unlawfulness' and corruption under Indonesian law. Bulletin of Indonesian Economic Studies. 45(2)179-198. See also Butt, Simon. (2011). Anti-corruption reform in indonesia: an obituary? Bulletin of Indonesian Economic Studies. 47 (3), 381-394.And Butt, Simon.(2012a).Corruption and Law in Indonesia. London: Routledge.
} 
some of the clearly deleterious reform proposals put forward by civil society organisations and the government and then speculate about the future of the regional Tipikor courts.

\section{The Establishment and Jurisdiction of Regional Tipikor Courts}

Prior to the establishment of regional Tipikor courts, corruption cases were handled by either the sole anti-corruption court in Jakarta or one of Indonesia's more than 300 district courts. Whether a case was heard in the Tipikor court or in one of these general courts largely depended on which institution investigated the case. The cases investigated or prosecuted by the national police for or public prosecution service were heard in Indonesia's general courts - which hear most of Indonesia's criminal and civil cases.

On the other hand, if allegations were investigated by Indonesia's AntiCorruption Commission (Komisi Pemberantasan Korupsi, or KPK), then the case would be heard in the sole Jakarta Tipikor Court. ${ }^{8}$ The KPK cannot investigate all corruption cases, however. Under the 2002 KPK Law, it can commence its own corruption investigations and prosecutions only if the case involves law enforcement officers or governments officials, attracts significant public concern or has led to a loss to the state of at least Rp 1 billion (Article 11). The KPK can also take over investigations and prosecutions from police and prosecutors, but only in particular circumstances. These include if police and prosecutors fail to respond to a corruption allegation made by the community, take a long time to pursue a corruption case, or are suspected of corruption themselves when handling a case (Article 9). The KPK can also take over from the police or prosecutors if the legislature, executive or judiciary interfere in the handling of a corruption case or if the case is particularly difficult or complex (Article 9).

The KPK was established for several reasons. One was to prevent ordinary police, prosecutors and courts from pursuing corruption cases that involved their own colleagues ${ }^{9}$. Another was to ensure that hand-picked and well trained police investigators and prosecutors handled corruption cases with high financial or political stakes. A large number of ordinary police and prosecutors were widely considered to be corrupt, therefore making them largely unsuitable or unable to professionally pursue corruption cases. As one common Indonesian idiom has it: "it is impossible to sweep the floor clean with a dirty broom". Indonesia's judiciary was also, generally speaking, notoriously corrupt and many judges were said to lack the necessary training to handle complex financial matters, including corruption cases. The Jakarta Tipikor Court was established in 2004 to adjudicate the prosecutions brought by the KPK.

Remarkably, since its establishment, the Jakarta Tipikor Court has maintained a $100 \%$ conviction rate in the cases prosecuted by the KPK, of which there have been more than 250. All convictions were upheld on appeal to the high and Supreme Courts, including those of quite senior government officials and parliamentarians, both past and serving. For this conviction rate the court

${ }^{8}$ The KPK was established in 2003 through Law No 30 of 2002 on the KPK. It comprises five commissioners and around 750 employees, which include seconded police officers and prosecutors. The Commission has several functions, including investigating and prosecuting corruption cases and running programs aimed at preventing corruption.

9 Fenwick, S. (2008). 'Measuring Up? Indonesia's Anti-Corruption Commission and the new corruptionagenda', in Timothy Lindsey (ed.) Indonesia: Law and Society. 2nd edition Annandale, N.S.W: Federation Press. 
has often been lauded as a 'success' in the fight against corruption in Indonesia. (Though I argue below that using this benchmark is highly problematic) This 'success' was attributed to several factors, two of which I will briefly mention. The first was that, as mentioned, the Jakarta Tipikor Court was the exclusive for um for KPK prosecutions. Ordinary prosecutors could not prosecute there; they could only appear before the general courts. The KPK was, generally speaking, better resourced than ordinary police and prosecutors, and their personnel better trained. KPK prosecutors established a reputation for preparing and presenting their evidence and argument in ways that made them more persuasive and, therefore, more likely to be accepted by a court.

The second commonly-accepted explanation for the conviction rate was that three ad hoc judges and two career judges presided over each case. These ad hoc judges were people, usually with legal experience, called in to serve as judges for a specified period. The rationale for having ad hoc judges was that they were less likely to be involved in the corrupt practices in which a significant proportion of ordinary career judges were thought to partake ${ }^{10}$. Because the ad hoc judges formed a majority on each panel, even if the integrity or competence of the career judges on the panel was questionable, the will of 'outsiders' would hold sway and prevail in a split decision. The career judges, however, were necessary because they had the experience in running trials and writing judgements that most ad hoc judges lacked.

\section{A. The KPK and Jakarta Tipikor Court's 'success' in context}

The overall contribution of these convictions should not be overstated, however. The vast majority of corruption investigations were initiated by Indonesia's police force and, if enough evidence was collected to proceed, then taken to a general court by Indonesia's prosecution service. During 2004-2011, public prosecutors brought 7371 corruption prosecutions before Indonesia's general courts. By contrast, the KPK brought only 233 prosecutions before the Tipikor court. As the following table shows, in its first four years, the KPK was able to bring, on average, just over 20 cases per annum and in 2008-2011 just over 40 cases per year. These numbers pale in comparison with the number of cases brought by public prosecutors which, in 2009 and 2010, peaked at 1824 and 1715 cases respectively.

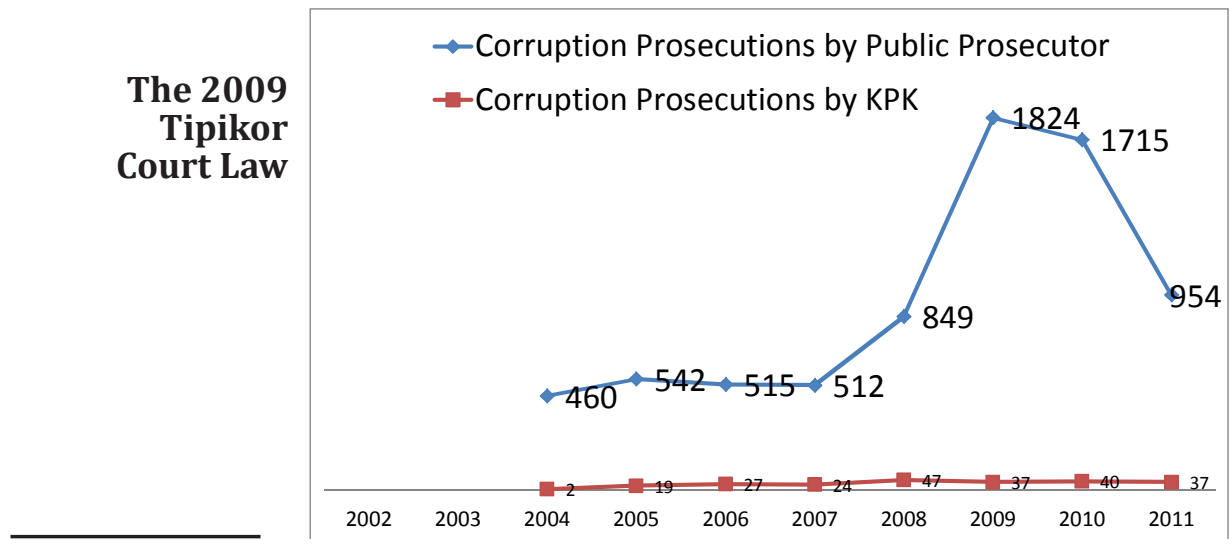


Within the first few years of the establishment of the Jakarta Tipikor Court, several of those convicted by the Court challenged the constitutionality of the laws under which they had been convicted before Indonesia's Constitutional Court $^{11}$. In one such case, decided in 2006, the Constitutional Court held that the two track system for handling corruption cases described above breached the constitutional principle of equality before the law ${ }^{12}$. Cases involving defendants investigated and prosecuted by the KPK and tried in the Tipikor court were governed by provisions of the 2002 KPK Law designed to make corruption convictions more likely, by providing special powers to KPK investigators and the Tipikor Court. By contrast, if the KPK chose not to pursue a particular corruption case, or lacked jurisdiction to do so, then ordinary police, prosecutors and courts would handle it under different, more stringent, procedures. Two separate defendants charged with the same crime could, therefore be investigated and tried under quite different procedures depending on whether the KPK decided to take on the case. Although the Constitutional Court did not put it quite so starkly, if the KPK proceeded to trial then conviction was virtually assured. But if handled by ordinary prosecutors and courts, defendants had an even chance of being acquitted, as discussed below. The Court ordered the national parliament to enact new legislation to remove this 'dualism', such as by transferring jurisdiction over corruption cases from the general courts to the Tipikor court.

Almost three years later, the national Parliament enacted Law No 46 of 2009 in response to this Constitutional Court decision. However, rather than simply transferring jurisdiction over all corruption cases to the sole Jakarta Tipikor Court, this Law required the Supreme Court to establish 33 regional Tipikor courts within two years. As mentioned, by the end of 2010, the Supreme Court had established three regional Tipikor Courts, ${ }^{13}$ and in 2011 set up the remaining 29 courts in two tranches. ${ }^{14}$

To some reformists, establishing 33 new Tipikor courts might have seemed to be an advance. The performance of the Jakarta Court had been widely praised and if its successes could be replicated across Indonesia, then corruption convictions would surely increase. In any event, establishing new corruption courts was also necessary if jurisdiction over corruption cases was to be transferred from the general courts. According to figures cited above, the KPK and ordinary prosecutors together pursued over 7500 corruption cases between 2004 and 2011 -an average of around 1000 per year. Clearly the Jakarta Tipikor Court could not handle these cases itself. However the establishment of these regional courts has raised significant problems, some of which I address below.

\footnotetext{
${ }^{11}$ Butt, Simon.(2009a). Indonesia's anti-corruption drive and the Constitutional Court. Journal of Comparative Law. 4(2)186-204.

${ }^{12}$ Butt, Simon.(2009a). Indonesia's anti-corruption drive and the Constitutional Court.Journal of Comparative Law. 4(2)186-204.

${ }^{13}$ By virtue of Supreme Court Chief Justice Decision 191/KMA/SK/XII/2010, 10 December 2010.

${ }^{14}$ Kompas (2012d) Vonis Tak Beri Efek Jera : Pengadilan Tipikor Bebaskan 71 Terdakwa Korupsi. Kompas. 2 August.

Supreme Court Chief Justice Decision 022/KMA/SK/II/2011, 7 February 2011 established Tipikor courts in Medan, Padang, Pekanbaru, Palembang, Tanjung karang, Serang, Yogyakarta, Banjarmasin, Pontianak, Samarinda, Makassar, Mataram, Kupang, dan Jayapura; Supreme Court Chief Justice Decision 153/KMA/SK/X/2011, 11 October 2011 established Tipikor courts in Banda Aceh, Tanjung Pinang, Jambi, Pangkal pinang, Bengkulu, Palangkaraya, Mamuju, Palu, Kendari, Manado, Gorontalo, Denpasar, Ambon, Ternate, and Manokwari.
} 


\section{The Acquittal Rate and Impropriety}

As mentioned, the focus of critique of the new regional Tipikor courts - usually levelled by civil society organisations such ICW, lawyers, and in the media - is that these courts have not maintained the $100 \%$ conviction rate of the first Jakarta Tipikor Court. Various media outlets have reported ICW claims that from December 2010 until 1 August 2012 regional Tipikor courts have acquitted 71 defendants, as indicated in the following table.

\begin{tabular}{|l|c|}
\hline \multicolumn{1}{|c|}{ Tipikor Court } & Number of acquittals \\
\hline Surabaya & 26 \\
\hline Samarinda & 15 \\
\hline Semarang and Padang & 7 \\
\hline Bandung & 5 \\
\hline Serang & 2 \\
\hline $\begin{array}{l}\text { Banda Aceh, Makassar, Palembang, } \\
\text { Jambi, Serang, Manado, Kupang, } \\
\text { Ambon, Kendari and Manokwari }\end{array}$ & 1 \\
\hline \multicolumn{1}{|c|}{ Total } & 71 \\
\hline
\end{tabular}

Source: Kompas, 2012c.

As the table indicates, the Surabaya Tipikor court has acquitted more defendants than any other. Nineteen of its acquittals were issued in the first four months of the court's existence ${ }^{15}$. In Samarinda, the Tipikor court acquitted 14 regional parliamentarians from the Kutai Kartanegara DPRD. Most media attention, however, has focused upon the Semarang Tipikor Court's acquittals and the perceived questionable integrity of its judges. Although it has acquitted no more defendants than have the Surabaya, Samarinda or Padang courts, it has a high perceived acquittal rate (including four acquittals in January-March 2012 alone). For excessive acquitting, one of its judges, Lilik Nuraini, was even transferred on the recommendation of the Judicial Commission. Nuraini had chaired panels that had acquitted in at least six cases. ${ }^{16}$

Worse, in August 2012 the KPK arrested Semarang Tipikor court ad hoc judge Kartini Juliana Magdalena Marpaung for allegedly receiving a bribe. According to media reports, she was caught red handed receiving around $\mathrm{Rp}$ September.

15 Surya Online (2012a) Hakim Tipikor Surabaya Bebaskan 19 Koruptor. Surya Online. 17

16 Kompas (2012b) SidangSoemarmo: SuapInstruksiWali Kota. Kompas. 26 June. Acquitted included Agus Soekmaniharto (defendant in land compensation case for building of tollroad between Semarang and Solo, acquitted 10 January 2012), Untung Wiyono (former Bupati of Sragen and defendant in the KabupatenSragen regional budget corruption case), Yanuelve Etliana (accused of Bank Jateng fraud worth 39 billion, acquitted 29 February 2012) and Heru Djatmiko (prosecuted for allegedly bribing two officials in Kabupaten Kendal in relation to the development of Bahurekso Main Stadium and Brangsong school in 2004) (Kompas, 2012a). Also acquitted in the Semarang Tipikor were Oei Shindu Stefanus (defendant in online population administration corruption case in Cilacap, acquitted on 21 October 2011), Suyatno (accused of bribing former Kendal Bupati Hendy Boedoro, acquitted on 8 March 2012), and Teguh Tri Murdiono (defendant in case involving procurement of fictitious Radio Republik Indonesia transmitter in Purwokerto)(Parwito, 2012). 
150 million (US $\$ 15,806)$ from Heru Kusbandono, a Tipikor court judge from Pontianak, West Kalimantan, who was allegedly acting as a 'case broker' for a matter the Semarang Tipikor Court was deciding and delivered the money to Kartini. The media named Sri Dartuti as the person who gave Heru the bribe to pay to Kartini. Sri Dartuti is the younger sister of the former Speaker of the Grobogan Regional House of Representatives, Muhammad Yaeni. The KPK revealed to the press that it suspected that the payoff was intended to ensure the acquittal of Yaeni in a corruption case concerning the misuse of funds for maintenance of the Grobogan parliament's official cars in 2006-2008 - a case involving around Rp 1.9 billion $^{17}$. Other judges on the panel hearing the case were also reported to have received bribes. In fact, Tempo magazine reported that one judge, Pragsono, in a meeting with the Supreme Court Chief Justice about the case, admitted to having been the first judge to see Heru as part of efforts to 'fix' the Yaeni case. Pragsono even admitted to protesting that the bribe was only Rp 100 million and pushing Heru to increase it to 150 million $^{18}$. According to the Jakarta Post (2012), Kartini had also acquitted four corruption defendants. ${ }^{19}$ As a result of these allegations of judicial impropriety, the KPK itself has asked the Semarang Tipikor court to hand over particular cases to the Jakarta Tipikor Court for trial rather than hearing those cases itself. ${ }^{20}$

Critics of the regional Tipikor courts appear to presume that these acquittals are, at least for the most part, indications of judicial impropriety and, to add weight to this claim, they point to the Semarang Tipikor court judge bribery investigation. They also refer to ICW-led research that found that 84 career judges in 14 Anti-corruption courts had 'problematic' integrity, quality and administrative skills ${ }^{21}$. This assessment was based on the failure of most of these judges to comply with mandatory asset reporting requirements and on some of them having been reported to the Judicial Commission and Supreme Court for breach of the Judicial Ethics Code, including by continuing to work as lawyers and meeting with lawyers outside of court ${ }^{22}$. In short, critics appear to assume that the acquittals in corruption cases are inevitably the result of undue influence, such as a bribe paid by the defendant to one or more judges presiding over his or her case.

\section{A. Is the Regional Tipikor Courts' Acquittal Rate High?}

The precise acquittal rate of the Tipikor courts and Indonesia's general courts in corruption cases is obscured by incomplete and perhaps unreliable data. According to ICW's estimate, in 466 cases decided by regional Tipikor courts, 71 (or 15 percent) defendant were acquitted and in 395 (or $85 \%$ ) the

${ }^{17}$ Tempo (2012b) Hybrid judges. Tempo. 3 September.

${ }^{18}$ ibid

${ }^{19}$ Aritonang, op.cit., Defendants included Yanuelva Etliana, accused of involvement in a Rp 39 billion fraud at the Central Java Regional Development (BPD, Bank Pembangunan Daerah) Bank; Untung Wiyono, former regent of Sragen in Central Java, allegedly involved in a budget scandal worth Rp 11.2 billion; Suyatno, a defendant in a corruption caseworth Rp 13.5 billion; and Heru Djatmiko, a defendant in a Rp 5.9 billion graft case.

${ }^{20}$ Notably, the trial of Semarang Mayor Soemarmo Hadi Saputro from the Indonesian Democratic Party of Struggle (PDI-P or Partai Demokrasi Indonesia - Perjuangan).

${ }^{21}$ Hukumonline (2012c) ICW: 84 Hakim Tipikor Dinilai Bermasalah. Hukumonline. 29 August <at: www.hukumonline.com>

${ }^{22}$ Hukumonline (2012c) ICW: 84 Hakim Tipikor Dinilai Bermasalah. Hukumonline. 29 August <at: www.hukumonline.com> 
defendant was convicted. By the count of Tempo magazine, perhaps the most highly respected press publication in Indonesia, only 40 defendants have been acquitted. Unfortunately, Supreme Court figures do not specify the conviction rate in corruption cases heard in the general courts. According to the Supreme Court's annual report ${ }^{23}, 872$ cases were lodged with Indonesia's 33 regional courts in 2011. In 2010, 392 had been lodged but not decided. These 33 courts, therefore, had 1264 cases pending in 2011. According to the Supreme Court, 'almost all' of these decisions were appealed to a high Tipikor court ${ }^{24}$. Appeal courts decided 466 corruption cases in 2011 (which included appeals from general courts in corruption cases decided before exclusive jurisdiction of a corruption cases was handed to the Tipikor courts), leaving 798 to be decided in 2012. Appeal court acquittal rates are not available.

Although the precise conviction rate of the general courts in corruption cases heard before the regional Tipikor courts were established is a matter of some dispute, the available evidence indicates that the conviction rate of the regional Tipikor courts was slightly higher. Supreme Court data was only available for 2008 and 2009. In those years, 1332 corruption cases were submitted to first instance and appeal courts. In 1055 (that is, 83.14 percent of) cases, the defendant was convicted; in 214 (that is, 16.86\%) the defendant was acquitted. ${ }^{25}$ The conviction rate of the regional Tipikor courts, then, appears to be only only marginally higher than the conviction rate of the general courts, if only in those two years.

By contrast, according to ICW statistics - which are disputed by the Supreme Court - the discrepancy between the conviction rates of the regional Tipikor courts and general courts is much larger. ICW estimates that in 20052009 , the general courts heard 857 corruption cases and acquitted around 50\% of the 1965 defendants. ${ }^{26}$ Given the Supreme Court's superior access to court data perhaps its figures should be accorded greater credence, even though they are incomplete. On the available data, then, it seems reasonable to conclude that the acquittal rate of the regional Tipikor courts is certainly no higher than the

${ }^{23}$ Mahkamah Agung (2012) Laporan Tahunan 2011. [online]

${ }^{24}$ Ibid

${ }^{25}$ On appeal, the Supreme Court acquitted only six defendants out of 240 cases and in fact overturned 56 lower court acquittals. I have not taken these Supreme Court appeal figures into account when determining the general courts' conviction rate because appeals from the regional Tipikor courts are also heard by the Supreme Court. Indeed, in at least three cases the Supreme Court has overturned first instance and appeal Tipikor court acquittals. For example in March 2012, a Supreme Court panel unanimously upheld an appeal lodged by KPK prosecutors against the acquittal of former Bekasi Mayor Mochtar Mohammad by the Bandung Tipikor Court. The Supreme Court sentenced him to six years' imprisonment, ordering him to repay Rp 639 million and fining him Rp 300 million. The Supreme Court found that he had been proved guilty (validly and convincingly) of breaching Articles 2(1) and 18 of the ACL for his involvement in several cases, including the PialaAdipura bribery case, misuse of the Bekasi budget, bribery of the BPK, and misuse of the regional food and beverage budget (Hukumonline, 2012f). The Supreme Court also overturned the acquittal of Former Bupati of East Lampung, Satono, by the Tanjung Karang Tipikor court, sentencing him to 15 years' imprisonment for corruption in the banking sector, ordered him to repay Rp 10.586 billion and fined him Rp 500 million (Hukumonline, 2012d). The Supreme Court also overturned the acquittal by Tanjung Karang Tipikor court of the former Central Lampung Bupati Finally, the Supreme Court overturned the acquittal of former Subang Bupati Eep Hidayat for corruption relating to land and building tax, and sentenced him to five years in prison, ordered him to replay Rp 2.548 billion and fined him Rp 200 million fine. Supreme Court found that he had been proven to have committed the corruption crime mentioned in the primary indictment (Hukumonline, 2012e).

${ }^{26}$ According to ICW, $22 \%$ of defendants were convicted in $2005,31 \%$ in $2006,56 \%$ in $2007,62 \%$ in $2008,59 \%$ in 2009 and, in the first half of 2010, 55\% were convicted (Hukumonline, 2010). 
general courts. At worst, the conviction rates between these courts seem to be comparable. Only if assessed by reference to the almost $100 \%$ conviction rate of the sole Jakarta Tipikor Court does the regional courts acquittal rate seem high.

\section{B. Acquittal Rates as Measures of Success}

Using acquittal rates to measure the success of the Tipikor courts is, however, highly problematic. As mentioned, these rates are usually taken as an indication that some form of judicial impropriety, usually corruption, has taken place and that, therefore, the defendant should have been convicted ${ }^{27}$. Supreme Court Deputy Chief Justice Artidjo Alkostar, widely regarded as 'reformist', claims, with pride, that 'If a corruptor's file ends up on my desk he won't get away'28. Yet an acquittal is not always an indication of corruption or 'softness' in the handling of the case. There are many other reasons why a judge might order the acquittal of a defendant in a corruption case.

Like most countries around the world, Indonesia's legal system provides for the presumption of innocence, even in corruption cases. ${ }^{29}$ Yet judging the performance of a court by its conviction rate presumes that all defendants appearing before the Tipikor courts are guilty ${ }^{30}$. And it ignores one of the most important purposes of criminal trials in Indonesia and elsewhere: namely, to allow both the prosecution and the defence to put forward evidence to support arguments indicating guilt or innocence, allow the other side and the court to scrutinise that evidence, and then leave the court to decide whether sufficient evidence exists to convict the defendant, taking into account any extenuating circumstances. Because the burden of proof lies with the prosecution, '[i]f the prosecution cannot convince the presiding judges of the defendant's guilt then the judges must acquit the defendant. ${ }^{31}$

Exclusive reliance on acquittal rates also oversimplifies the complexities of legal processes and ignores quite legitimate reasons judges may have to throw out a case or to order an acquittal. Under Indonesian law, judges must be convinced of the defendant's guilt and that the defendant's guilt has been proven in legal way. In this context, if any of the following questions are answered in the negative, then an Indonesian judge could, perhaps should, throw out a case or acquit the defendant. Does the prosecution's indictment clearly and comprehensively set out the facts that constitute the elements of the crime or crimes of which the defendant has been accused? Did prosecutors set out the applicable statutory provisions for that crime? Did the prosecution present evidence that was valid under Indonesian law and that convinces the judges that not only a crime was committed but that the defendant committed it? ${ }^{32}$

\footnotetext{
${ }^{27}$ Pratama (2012) Quo Vadis Pemberantasan Korupsi. Hukumonline. 9 September.

${ }^{28}$ Tempo (2012a) Artidjo Alkostar: If a corruptor's file ends up on my desk he won't get away. Tempo. 16 August.

${ }^{29}$ Although it should be noted that under Article 37 of Indonesia's 1999 Anticorruption Law, the defendant in a corruption trial might be required to prove the source of monies in his or her bank accounts so as to prove that they were not derived from corruption.

${ }^{30}$ Pratama, op., cit March/April.

${ }^{31}$ Butt, Simon (2012b) Regional anti-corruption courts: A wolf in sheep's clothing. Inside Indonesia.

${ }^{32}$ Butt, Simon (2008) Indonesian terrorism law and criminal process. Islam, Syari'ah and Governance Background Paper Series, ARC Federation Fellowship, University of Melbourne.
} 
Did the defendant's lawyers challenge the authenticity or veracity of important prosecution evidence, leaving the court no choice but to give that evidence little or no weight? In corruption cases, did the defendant provide a plausible explanation for loss to the state that showed that he or she did not engage in corruption or other illegality?

Some press accounts have reported that Tipikor courts acquitting, in my view quite properly, in some of these very circumstances. For example, the Surabaya Tipikor court appeared to have very little choice but to acquit defendants in at least five cases because charges in the indictments breached statutory limitations period imposed by the Indonesian Criminal Code $^{33}$. In a further nine cases, the Surabaya court threw out indictments because they failed meet the formal requirements of Indonesian criminal procedure law ${ }^{34}$. For example, in one case, prosecutors mentioned the wrong gender of the defendant in their indictment; in another, prosecutors were unable to locate the defendant and bring him or her to trial, but did not specifically ask the court to hear the case in absentia (in the absence of the defendant); and in yet another, prosecutors referred to provisions of the 1999 Corruption Eradication Law that did not exist ${ }^{35}$. It is difficult to see how courts can do anything but free the defendant in the circumstances.

\section{Conviction at The Expense of Legal Principle?}

Some critics have argued that the Jakarta Tipikor Court must have compromised the presumption of innocence in some cases to maintain its conviction rate. Although, as mentioned, the KPK is widely regarded as being far more professional than the ordinary police and prosecutors in the handling of evidence and presenting cases, it is not perfect. It seems inconceivable that, over 250 cases, the KPK has made no mistakes or that the defendant has been unable to cast doubt on the evidence presented against him or her, thereby justifying an acquittal. In response, reformers might argue that corruption is an extraordinary crime the effect of which is so deleterious that extreme measures and are justified to eradicate it. Although such arguments may be well intentioned, ignoring fundamental legal principles to secure convictions damages Indonesia's progress towards the rule of law. Rather than trying to increase the conviction rates of regional Tipikor courts, perhaps reformists should channel their efforts into assessing the fairness of regional Tipikor court trials or highlighting the need for tougher sentences for those actually found guilty of corruption. Regional Tipikor courts have, for the most part, issued prison terms of only one or two years and some convicts have faced only city detention $^{36}$, even though the 1999 Corruption Eradication Law provides quite stiff penalties for breach.

The presumption of innocence might not have been the only legal principle being discarded in the Jakarta Tipikor Court in the name of obtaining convictions. For example, in 2012 Miranda Goeltom was convicted and sentenced to three years' imprisonment for her part in a scheme to provide parliamentarians

\footnotetext{
${ }^{33}$ Musahadah (2012) 10 Perkara Korupsi Ditolak Pengadilan Tipikor. Surya Online. 12 july.

${ }^{34}$ Musahadah (2012) 10 Perkara Korupsi Ditolak Pengadilan Tipikor. Surya Online. 12 July.

35 Surya Online (2012a) Hakim Tipikor Surabaya Bebaskan 19 Koruptor. Surya Online. 17 September.

${ }^{36}$ Kompas (2012c) Vonis Bebas Pengadilan Tipikor. Kompas. 2 August.
} 
with bags filled with travellers' cheques in return for voting to install her as a Bank Indonesia's deputy governor in 2004. Around 30 parliamentarians were convicted for taking bribes in this case. Initially, prosecutors had sought to charge her with offences that were subject to the statutory limitation period mentioned in Article 78(1)(2) of the Criminal Code ${ }^{37}$. Prosecutors had run out of time to bring these charges against her. The judges hearing the case should have, therefore, thrown these charges, and perhaps the entire indictment, out of court, on grounds that the court lacked jurisdiction to consider those charges. However, by Pratama's account, prosecutors argued that in the interests of utility Article 78(1)(2) should be simply ignored in the case and the court agreed. Pratama suggests that the judges might have been afraid that following the Criminal Code would result in them being labelled 'anti anticorruption'. They might have been afraid of ruining the conviction rate of the Jakarta court. Whatever the reason, it seems that the Criminal Code was clearly breached. The Court should have stood in the way of these attempts by prosecutors and could have, in this case, probably simply asked prosecutors to proceed using other charges that also carried significant penalties.

If the performance of the Jakarta Tipikor court is assessed by reference to its provision of a fair trial and adherence to legal principle, then, it may be far from a 'success'. And, without evidence to the contrary, it may be that regional Tipikor courts are complying with the law by acquitting. Unfortunately, the only ones to complain about the fairness or otherwise of Tipikor court trials have been defence lawyers who have lost cases in the Jakarta court. Their views are, however, often discredited by so-called reformists and government officials. For example, Deputy Minister for Law and Human Rights Denny Indrayana recently announced via twitter that 'The advocates (who defend) corruptors are corruptors themselves. Advocates that defend corruptors and receive payment from the proceeds of corruption are themselves corruptors' ${ }^{38}$ Once again, this statement appears to presume that defendants in corruption cases are guilty, even before they have been tried.

\section{A. Judicial Integrity in Context}

Finally, it is somewhat unfair to criticise the integrity of Tipikor courtjudges without putting those criticisms in their proper context. Thus far, as mentioned, only two of Indonesia's 150 or so Tipikor court judges have been investigated for corruption and one had been disciplined for perceived excessive acquitting. At time of writing neither had been convicted of an offence. Allegations of judicial impropriety, including corruption, are certainly common in Indonesia. In late 2011 and in early 2012, the KPK prosecuted, and the Jakarta Tipikor Court convicted, at least three general court judges for corruption ${ }^{39}$. And, in 20052010, the Judicial Commission investigated 376 judges, recommending to the Supreme Court that 97 of them be sanctioned by written reprimand, suspension or dismissal, including for alleged corruption. ${ }^{40}$ The Supreme Court disciplined

\footnotetext{
${ }^{37}$ Pratama, (2012)., op., cit

${ }^{38}$ After being reported to police for defamation for these comments by one of Indonesia's most famous advocates, OC Kaligis, Denny apologised for the statement (Hukumonline, 2012a).

39 Jakarta Globe (2012) Criticism as Indonesia Judge Gets Just Four Years Jail For Corruption. Jakarta Globe. 29 February

${ }^{40}$ The Commission suggested that 16 be dismissed, 36 be suspended for up to two years and 45 be issued with a written reprimand (Judicial Commission, 2011, pp.60-61).
} 
50 judges from across Indonesia in 2011 alone, though only seven judges were dismissed and four were transferred for misconduct. ${ }^{41}$

\section{Real Problems Obscured by Obsession with Acquittals}

The 2009 Tipikor Court Law did not only require the establishment of 33 new Tipikor courts. It also made very important changes to the way that corruption cases are now prosecuted and adjudicated. ${ }^{42}$ The focus upon the acquittals and integrity of regional Tipikor court judges has, in my view, distracted attention from two real problems the Tipikor Court Law brought to the handling of corruption cases in these courts. To be sure, these problems are not entirely neglected. Rather, they are not being given the attention they deserve by reformists in civil society and government alike. Here I focus on two changes that are of particular significance. Both appeared to be necessary 'evils' if jurisdiction over corruption cases was to remain in the hands of specialist Tipikor courts. But both changes also roll back aspects of institutional design that appeared to contribute to the Jakarta Tipikor Court's 'success'.

The first change is that career judges can now potentially constitute the majority in trials held in the Tipikor courts. The statute allows the chairperson of the district court in which the Tipikor court is housed to determine whether ad hoc or career judges will constitute the majority on each panel. Even though the Supreme Court has indicated a clear preference that ad hoc judges outnumber career judges in each case, this is not always possible. As mentioned, the Supreme Court has encountered significant difficulties in recruiting sufficiently qualified ad hoc judges to sit on regional Tipikor courts. ${ }^{43}$ The result is that there is a shortage of ad hoc judges; some district courts do not have enough ad hoc judges to sit in corruption cases let alone constitute majorities on panels. A Supreme Court Regulation ${ }^{44}$ also gives the chairperson of a district court power to allocate three rather than five judges to a case if, according to the prosecutor in the case, the loss to the state is less than Rp 3billion. In practice many court chairpersons have no choice but empanel a three-judge panel with a career judge majority. This means that career judges now have the final say in many cases heard in regional Tipikor courts. In a press interview, KPK Chairperson Abraham Samad describe having panels with two career and one ad hoc judge as one of the biggest problems affecting the quality of regional Tipikor courts,

\footnotetext{
${ }^{41}$ Mahkamah Agung, (2012)., op., cit

${ }^{42}$ Sceptics speculated that the 2009 statute was designed to weaken the Tipikor courts. While the parliament was deliberating the statute, the KPK was investigating dozens of parliamentarians for corruption, most of which had been allegedly perpetrated whilst in office. These parliamentarians would likely have had an interest in a weakened Tipikor court system, given that they could foresee being prosecuted in them. The KPK was investigating several cases, but perhaps most notable was the so-called travellers cheque scandal involving Miranda Goeltom, mentioned above.

${ }^{43}$ The Supreme Court only received Rp 2.5 billion from the State budget to select 244 Tipikor Court judges across all provinces. This is a very small amount considering that the KPK received Rp 2 billion to select just one replacement (Detik News, 2011). One critique of the candidates identiied thus far is that many of them are former or practising lawyers, some of which have represented defendants in corruption cases. Presumably this criticism runs along the lines of Deputy Minister Indrayana's description of such lawyers as 'corruptors themselves'. Little regard seems to be had for the opposite view, that is, that those with previous experience handling corruption cases on behalf of clients are likely to have an intricate knowledge of the anticorruption law and the way that the Tipikor courts operate - both skills necessary for effective service as as a judge on a Tipikor court

${ }^{44}$ Supreme Court Regulation1 of 2010 on the Organisational Registrar Structure, Makeup of the Bench and Openness of the Anti-Corruption Courts.
} 
adding that: 'I appreciate our many judges who are good, but I cannot close my eyes to the many of our career judges who are bad'.45

The second detrimental but arguably essential change is that ordinary prosecutors can now bring cases before all Tipikor courts. The vast majority of cases brought before the regional Tipikor courts are now run by ordinary prosecutors. However, allowing ordinary prosecutors to appear in Tipikor courts appears to be a necessity. In September 2012, the KPK had only 88 investigators seconded from the police force and 44 public prosecutors. On average, four investigators work on a single case, and each investigator deals with three to seven cases at any one time (Anton Septian, 2012). The KPK seems, therefore, to lack the resources necessary to investigate (and, if necessary, prosecute) the many corruption allegations raised each year. The KPK also does not have regional offices, often making it very difficult to investigate and prosecute in regional areas. Unless the KPK is radically expanded, there seems little alternative but to allow ordinary prosecutors to appear in these courts, even though the professionalism of KPK prosecutors was widely considered as a key factor in the Jakarta Court's conviction rate.

These changes have, for the most part, brought Indonesia's legal infrastructure for handling corruption cases back to the framework in place before the establishment of the KPK in 2003 andthe Jakarta Tipikor Court in 2004. As mentioned, the primary rationale for establishing these institutions was to take at least some corruption cases away from ordinary police, prosecutors and courts, which were widely perceived to be corrupt themselves. This strategy was widely regarded as being successful, not only because of the Jakarta Tipikor Court's $100 \%$ conviction rate, but also because, particularly since 2008 , the KPK investigated and prosecuted, and the Jakarta Court convicted, powerful political figures that were virtually untouchable only several years earlier. They included governors, ministers, senior officials in Bank Indonesia and parliamentarians, both serving and past. This was thought to have a significant deterrent effect on those contemplating corrupt activities ${ }^{46}$. If having a majority of ad hoc judges on each five-judge panel brought a measure of impartiality and objectivity to the handling of corruption cases, and thereby improved the court's decision making, then giving back control over corruption cases to career judges appears to be a backward step. Of course, much depends on the quality of these ad hoc judges in regional Tipikor courts. If, as mentioned, the integrity and capacity of many of these ad hoc judges is questionable, then little might be gained from them forming a majority on the bench of a Tipikor court in any event.

It is perhaps more significant, however, that ordinary prosecutors now present the vast majority of cases the Tipikor court hears. In my view, this has two significant ramifications. First, generally speaking, Indonesian prosecutors do not have a reputation for high levels of integrity. Suspicions that prosecutors drop cases, lose evidence, sabotage cases or push for lenient sentences in return for bribes from defendants was one of the reasons for the establishment of the KPK in the first place ${ }^{47}$. Obviously, if these practices become common place in cases heard before the regional Tipikor courts, then appropriate sentences and convictions will be less likely.

\footnotetext{
${ }^{45}$ Antara. (2012). Ketua KPK Ragukan Kualitas Pengadilan Tipikor Daerah. Antara. 25 April.

${ }^{46}$ Butt, Simon. (2009b). 'Unlawfulness' and corruption under Indonesian law. Bulletin of Indonesian Economic Studies. 45(2)179-198.

${ }^{47}$ Fenwick., (2008)., op.cit
} 
Second, generally speaking, Indonesian prosecutors are not renowned for their competence. Like prosecutors everywhere, sometimes they mistakes in their indictments prompting presiding judges to throw out their cases. A telling example of this occurred in the first case brought by a public prosecutor before a Tipikor court. This case, tried in the Jakarta Tipikor Court, involved a former assistant, Mieke Henriett Bambang, to the former governor of Bank Indonesia who the KPK had been investigating for corruption. Prosecutors charged Bambang with evidence tampering which is an offence under the 1999 Anticorruption Law. A series of reports published by Hukumonline indicated that the quality of the prosecution was poor by comparison to the standards set by the KPK in the Jakarta Tipikor Court. Only one prosecutor appeared to present the indictment (the KPK usually sends at least two) and the indictment was very short (the KPK's indictments are often hundreds of pages). The court also found the indictment presented was not accurate, clear and complete as required by Article 142(3) of the Code of Criminal Procedure, largely because it did not clearly set out the crime of which Bambang was accused. The court threw out the case before witnesses were heard. ${ }^{48}$

\section{Conclusion: reform proposals and the future}

Indonesia's new regional anti-corruption courts are certainly far from perfect. Reports that some of their ad hoc judges lack competence and that some of their ad hoc and career judges lack integrity are credible. Yet there is little evidence to suggest that they are any worse than Indonesia's general courts, where problems of competence and integrity are well documented.

The performance of the Tipikor courts should not be judged on outcome alone. But even if one accepts that acquittals are evidence of failure, the available data indicates that the acquittal rates of regional Tipikor courts are in fact no higher than those of the courts they 'replaced' in 2011 - Indonesia's general courts. And, as the Supreme Court fills ad hoc judicial positions and regional Tipikor court judges gain more experience in corruption cases, many of which are highly complex, it is possible, perhaps likely, that ad hoc judges will eventually outnumber career judges in Tipikor courts and decision-making standards will improve. Despite their problems, the regional Tipikor courts should not, therefore, be abolished or recentralised as some politicians and senior legal figures proposed soon after the two regional Tipikor court judges were arrested in Semarang in August 2012. However, the obsession with acquittal rates must, in my view, be jettisoned. Those properly found guilty of corruption should, of course, be punished - perhaps even more severely than they have been in the Tipikor courts thus far. However, proper legal procedures and safeguards must be maintained, lest the rule of law be sacrificed. The system must be fair and impartial to remain credible and legitimate in the long term.

Greater resources need to be allocated to the Tipikor courts so as to attract high-quality applicants to fill ad hoc judicial positions. The KPK must be also receive greater funding so that it can increase the number of investigators and prosecutors that it employs, and thereby handle a greater proportion of corruption cases and perhaps even lift overall standards. A significant challenge is improving the professionalism of Indonesia's prosecutors. This will be a

${ }^{48}$ Butt, Simon. (2011). Anti-corruption reform in indonesia: an obituary? Bulletin of Indonesian Economic Studies. 47 (3), 381-394. 
very difficult and time-consuming task. Many previous attempts at reform within the Attorney General's and public prosecutor's offices have born little or no fruit. Nevertheless, on a positive note, the 'success' of the KPK and the Jakarta Tipikor Court seems to have spurred ordinary law enforcers into action. For example since the KPK began handling high-profile cases from 2008, the number of prosecutions brought by ordinary prosecutors spiked to a level that has remained high. And, since the Jakarta Tipikor Court was established, the Supreme Court has appeared intent on ensuring a high conviction rate in the general courts, at least in cases that are appealed to it.

However, the greatest challenge faced by Indonesia's anticorruption movement is neither the acquittal rate, nor the paucity of quality judges and prosecutors. It is Indonesia's national parliament. Over the past few years, proposals have abounded to draft a new statute to replace or amend the $2002 \mathrm{KPK}$ Law. Proposed drafts seek to require the KPK to obtain prior written permission from the chairperson of a local court to wiretap or intercept communications of those suspected of corruption ${ }^{49}$. This, according to some parliamentarians, is necessary to protect the privacy of citizens. Also proposed have been provisions establishing a KPK Monitoring Council appointed by the national Parliament and allowing the KPK to cease investigations of corruption cases at any stage ${ }^{50}$. Most alarming, however, is the proposal to removal the KPK's prosecutorial function altogether. Approval of this proposal into law would sound the death knell for Indonesia's anti-corruption drive.

\section{Bibliography}

\section{Books}

Butt, Simon\& Lindsey, Tim. (2010). "Judicial Mafia: The Courts and State Illegality in Indonesia", in G Van Klinken \& Edward Aspinall (eds.) The state and illegality in Indonesia. KITLV Press.

Butt, Simon. (2012a). Corruption and Law in Indonesia. London: Routledge.

Pompe, S. (2005) The Indonesian Supreme Court: A Study of Institutional Collapse.

Studies on Southeast Asia. Ithaca, N.Y: Southeast Asia Program, Cornell University.

Satgas Pemberantasan Mafia Hukum (2010) Mafia Hukum, Satgas Pemberantasan Mafia Hukum with the support of UNDP.

Supreme Court of Indonesia (2003) Policy paper on judicial personnel management reform. Jakarta: Supreme Court of Indonesia.

World Bank (2003) Combating Corruption in Indonesia: Enhancing Accountability for Development, World Bank, East Asia Poverty Reduction and Economic Management Unit, 2003.

Zakiyah Wasingatu, Widoyoko, Danang, Kasuma, Iva and Edi, Ragil Yoga (2002) Menyingkap tabir mafia peradilan, Jakarta, Indonesia Corruption Watch.

49 Hukumonline.(2012b). DPR BerusahaBatasiWewenangMenyadap KPK. Hukumonline. 25 September <at: www.hukumonline.com>.

${ }^{50}$ Koran Tempo (2012) PegiatAntikorupsitolakrevisi UU KPK. Koran Tempo. 25 September. 


\section{Articles}

Ambarita. (2012).Vonis Bebas Pengadilan Tipikor: 14 Terdakwa Divonis Bebas dalam 4 hari. Tribune News. 10 January.

Antara. (2012). Ketua KPK Ragukan Kualitas Pengadilan Tipikor Daerah. Antara. 25 April.

Aprianto, Anton \& Nofitra, Riyan. (2012). First PON, then the Forests of Pelalawan. Tempo. 31 August.

Septian, Anton. (2012). Paralysing the KPK. Tempo. 24 September.

Aritonang. (2012).Goverment Considers Shutting Down Corruption Courts in Regions. Jakarta Post. 21 August.

Sentinel, Asia. (2012). Indonesia's Graft Watchdogs Go for Bigger Targets. Asia Sentinel. 18 August.

Butt, Simon.(2008). Indonesian terrorism law and criminal process. Islam, Syari'ah and Governance Background Paper Series, ARC Federation Fellowship, University of Melbourne.

Butt, Simon.(2009a). Indonesia's anti-corruption drive and the Constitutional Court. Journal of Comparative Law. 4(2)186-204.

Butt, Simon.(2009b). 'Unlawfulness' and corruption under Indonesian law. Bulletin of Indonesian Economic Studies. 45(2)179-198.

Butt, Simon. (2011). Anti-corruption reform in indonesia: an obituary? Bulletin of Indonesian Economic Studies. 47 (3), 381-394.

Butt, Simon (2012b) Regional anti-corruption courts: A wolf in sheep's clothing. Inside Indonesia. March/April.

Fenwick, S. (2008). 'Measuring Up? Indonesia's Anti-Corruption Commission and the new corruption agenda', in Timothy Lindsey (ed.) Indonesia: Law and Society. 2nd edition Annandale, N.S.W: Federation Press.

Jakarta Globe (2012) Criticism as Indonesia Judge Gets Just Four Years Jail For Corruption. Jakarta Globe. 29 February.

Kompas (2012a) Pengadilan Tipikor: Empat Hakim di Semarang Diduga Langgar Kode Etik. Kompas. 19 June.

Kompas (2012b) Sidang Soemarmo: Suap Instruksi Wali Kota. Kompas. 26 June. Kompas (2012c) Vonis Bebas Pengadilan Tipikor. Kompas. 2 August.

Kompas (2012d) Vonis Tak Beri Efek Jera: Pengadilan Tipikor Bebaskan 71 Terdakwa Korupsi. Kompas. 2 August.

Koran Tempo (2012) PegiatAnti korupsi tolak revisi UU KPK. Koran Tempo. 25 September.

Musahadah (2012) 10 Perkara Korupsi Ditolak Pengadilan Tipikor. Surya Online. 12 July.

Parlina, Ina (2012) New KPK chief pleased with his first four months in office. Jakarta Post. 14 May.

Parwito (2012) PengadilanTipikor Semarang bebaskanpenyuapBupati Kendal. Suara Merdeka. 12 June.

Pratama (2012) Quo Vadis PemberantasanKorupsi. Hukumonline. 9 September. 
Surya Online (2012a) Hakim Tipikor Surabaya Bebaskan 19 Koruptor. Surya Online. 17 September.

Surya Online (2012b) Tipikor Gelar Sidang Perdana Mantan Bupati Kampar. Surya Online. 12 June.

Tempo (2012a) Artidjo Alkostar: If a corruptor's file ends up on my desk he won't get away. Tempo. 16 August.

Tempo (2012b) Hybrid judges. Tempo. 3 September.

Tempo (2012c) Out of order. Tempo. 17 September.

Tempo (2012d) Pengadilan Tipikor Daerah Diusulkan Dibubarkan. Tempo. 5 November.

\section{Websites}

Detik News. (2011). Pengadilan Tipikor, Kebijakan Setengah Hati. Detik News. 7 November.

Hukumonline (2010) Pengadilan Umum, Surga Pembebas Koruptor.

Hukumonline. (2011a). Busyro: UU KPK Tak Perlu Direvisi. 3 March <at: www. hukumonline.com>.

Hukumonline (2011b) PengadilanTipikor Jakarta BebaskanSeorangTerdakwa. 21 February<at: www.hukumonline.com>

Hukumonline (2011c) Pertama Kali Kasus Kejaksaan Disidang di Pengadilan Tipikor Jakarta.

Hukumonline. (2012a). Denny Indrayana Minta Maaf. Hukumonline. 27 August <at: www.hukumonline.com>.

Hukumonline.(2012b). DPR Berusaha Batasi Wewenang Menyadap KPK. Hukumonline. 25 September<at: www.hukumonline.com>.

Hukumonline (2012c) ICW: 84 Hakim Tipikor Dinilai Bermasalah. Hukumonline. 29 August<at: www.hukumonline.com>.

Hukumonline (2012d) MA BatalkanVonis Bebas Bupati Lampung Timur. Hukumonline. 19 March<at: www.hukumonline.com>.

Hukumonline (2012e) MA Batalkan Vonis Bebas Bupati Subang. Hukumonline. 22 February<at: www.hukumonline.com>.

Hukumonline (2012f) MA Batalkan Vonis Bebas Wali Kota Bekasi. Hukumonline. 7 March<at: www.hukumonline.com>.

Hukumonline (2012g) UU Kehutanan Lemah Berantas Kejahatan. Hukumonline. 23 May.

Judicial Commission (2011) Laporan Tahunan 2010. [online]. Available from: http://www.kpk.go.id/uploads/PDdownloads/Laptah_KPK_2004.pdf (Accessed 22 February 2011). [online]. Available from: http://www. kpk.go.id/uploads/PDdownloads/Laptah_KPK_2004.pdf (Accessed 22 February 2011).

Mahkamah Agung (2012) LaporanTahunan 2011. [online]. Available from: http://www.kpk.go.id/uploads/PDdownloads/Laptah_KPK_2004.pdf (Accessed 22 February 2011). [online]. Available from: http://www. 
kpk.go.id/uploads/PDdownloads/Laptah_KPK_2004.pdf (Accessed 22 February 2011). 